Working Papers in Economics

The Granger-Causality between Transportation and GDP: A Panel Data Approach

Mehmet Aldonat Beyzatlar, Dokuz Eylül University

Müge Karacal, Izmir University of Economics

I. Hakan Yetkiner, Izmir University of Economics

Working Paper \# 12/03

February 2012

Izmir University of Economics

Department of Economics

Sakarya Cad. No:156

35330 Balçova Izmir

Turkey 


\title{
The Granger-Causality between Transportation and GDP: A Panel Data Approach
}

\begin{abstract}
This study investigates the Granger-causality relationship between real per capita GDP and transportation of EU-15 countries using a panel data set covering the period 19702008. Our findings indicate that the dominant type of Granger-causality is bidirectional. Accordingly, we conclude that care must be paid in defining the dependent and independent variables when studying the relationship between transportation and income. Instances of one-way or no Granger-causality were found to correspond with countries with the lowest income per capita ranks in 1970 and/or in 2008, including Portugal, Greece and Italy. We speculate that bi-directional Granger causality between income and transportation is observed only after an economy has completed its transition in terms of economic development.
\end{abstract}

Keywords: Granger-causality, Transportation, Income

JEL Classification: C23, 018.

Mehmet Aldonat Beyzatlar

Department of Economics

Dokuz Eylül University

Izmir, Turkey 35160

Email: mabeyzatlar@hotmail.com

Müge Karacal

Department of Economics

İzmir University of Economics

Izmir, Turkey 35330

Email: muge.karacal@ieu.edu.tr

I. Hakan Yetkiner

Department of Economics

İzmir University of Economics

Izmir, Turkey 35330

Email: hakan.yetkiner@ieu.edu.tr 


\section{Introduction}

It is impossible to deny that we are in the age of mobility. It is no longer only physical goods that move between locations in bulk, but also human beings and services. The facilities that collectively make this unprecedented mobility possible are called transportation. A natural question that follows this observation is whether transportation does enhance economic development and growth or vice versa or a combination of both. Economic intuition suggests that transportation may have strong positive effects on economic development and growth, directly or indirectly, which we will call in this study direct causation. ${ }^{1}$ First and foremost, improvements in transportation and its facilities improve overall productivity of production activities. New developments in transportation (e.g., faster trains, oil tankers with more capacity) all contribute to increased productivity for production units (Bougheas et al. (2000); Lakshmanan (2007)). Secondly, increasing transportation eases technology spillovers across economies. At micro level, which may lead to macro results, transportation (infrastructure) increases profitability via reducing costs or increasing sales revenue, as transportation and its facilities allow firms to access the lowest cost inputs or factors of production for their production activities. Similarly, transportation and its facilities allow firms to access broader markets and perhaps at more advantageous prices.

On the other hand, it is clear that increasing demand for transportation is a reflection of a more fundamental global phenomenon: unprecedentedly increasing world income. Though its distribution may be unequal, the growing income, essentially due to technological progress, allows general demand to rise, forcing transportation to accommodate it. Hence, intuition suggests that income determines transportation, which we call in this study as reverse causation.

There is a growing body of research focusing on the relationship between transportation infrastructure and economic development. This research generally confirms positive effect of transportation, and a branch of this research considers infrastructure as an argument (factor) in production. It may be possible to call these studies "the production function approach". The

\footnotetext{
${ }^{1}$ Most of the studies in the literature refer to the effect of transportation on economic development as direct causation, and the effect of economic development on transportation as reverse causation as we do in this study. However, some studies use direct causation to mean the effect of economic development on transportation and reverse causation to mean the other way around.
} 
pioneering study of this approach (and also the relationship between infrastructure and development) is Aschauer (1989). He investigates the effects of public capital on the productivity of private sector, showing that the elasticity of private sector productivity with respect to public capital is positive. Munnell (1990) confirms that the relationship is positive (elasticity of 0.35). Munnell and Cook (1990) investigate the impact of highways on Gross State Product (GSP) where they show that the elasticity of GSP with respect to highways 0.06 on the positive side. Duffy-Deno and Eberts (1991), Eisner (1991), Garcia-Mila and McGuire (1992) and Moonmaw et al. (1995) similarly obtain positive relationships between transport infrastructure and per capita income by using production function approach. Jones (1990), Mofidi and Stone (1990), and Reynolds and Maki (1990) all study the effects of highway spending per capita on various measures of development. Jones (1990) and Mofidi and Stone (1990) show that highway spending per capita has positive impact on these measures, whereas Reynolds and Maki (1990) fail to find it. Singletary et al. (1995), Crihfield and Panggabean (1995), Garcia-Mila et al. (1996) and Fernald (1999) all show that increases in resources allocated to highways cause employment in the manufacturing industry to rise, leading to productivity growth.

Berndt and Hansson (1992), Lynde and Richmond (1993), Seitz (1993), Nadiri and Mamuneas (1994), Conrad and Seitz (1994) and Boarnet (1996; 1998) use "cost function approach" for the investigation of the relationship between transport measures and development for Sweden, United Kingdom, West Germany and USA. The common finding of these studies is that the effects of transport measures are cost reducing elements. Bougheas et al. (2000) also introduce infrastructure as a cost reducing technology in their cross country study and according to this approach, improvements in the transportation infrastructure allow specialization and long run growth. They show that, as a cost reducing technology, infrastructure makes production of intermediate inputs more efficient compared to its impact on the efficiency in production of final goods.

Another group of studies that we may label as "the capital approach", including Boopen (2006) and Zhou et al. (2007), examine the growth impact of transportation capital. In particular, Boopen (2006) uses a Cobb Douglas production function to regress total output on labor, physical capital and transportation capital. He shows that in Africa investment in transportation capital is more productive than physical capital (investment) on average. Zhou et al. (2007) show that highway construction in the correlation matrix for highways, growth and exports has significant and positive effect on economic 
growth in China. The study also stresses that the quality and the quantity of transportation infrastructure is crucial in terms of its contribution to economic development.

As stated above, intuition also suggests that it is increasing income that makes transportation possible, that is, higher income inevitably has a positive effect on transportation. Kim (2002) examines the determinants of optimal demand for transportation infrastructure using a recursive computable general equilibrium model, and under various scenarios of economic growth and inflation he finds that higher levels of transportation capital stock are associated with higher economic growth and inflation. Specifically, a $1 \%$ increase in gross domestic product (GDP) generates capital formation in transportation sector by $0.99 \%$. Using pooled cross-sectional and time series data on 27 low and middle income economies between 1980-1986, Randolph et al. (1996) find that per capita government expenditures on transportation and communication (T\&C) increase with GDP per capita among other things.

All these studies indicate clearly that there is a strong relationship between economic development and transportation, perhaps in both directions. However, if this relationship is bidirectional, then studies undertaking one-way relationship between transportation and income involve a misspecification problem. That is, ordinary least squares (OLS) estimation will produce biased and inconsistent estimates of the structural parameters given that there is an endogenous relationship between income and transportation. Therefore, it is critical to determine the direction of the causality between transportation and economic development (GDP per capita level) in advance. Applying the Granger-causality (or rather Granger non-causality) test is the most effective and practical way to test the direction of causality (Chamberlain, 1982; Florens and Mouchart, 1982).

We propose here a simple Granger non-causality test for heterogeneous panel data models, following Erdil and Yetkiner (2009). This test allows us to take into account both dimensions of the heterogeneity in this context: the heterogeneity of the causal relationships and the heterogeneity of the data generating process (Hurlin 2004a). To the best of our knowledge, the few studies that exist in this area show conflicting evidence. While some use panel data to test for causality others use time series data for various countries. Furthermore the variables used by these studies vary from public investment in $\mathrm{T} \& \mathrm{C}$ to road and highway infrastructure, and air passenger traffic as a proxy for public investment/ capital spending, and from GDP to agricultural productivity growth, and state level employment as a proxy for economic 
growth. Haque and Kim (2003), and Bose and Haque (2005) both examine the relationship between public investment in $\mathrm{T} \& \mathrm{C}$ and economic growth by applying Granger causality test using panel data for different sets of developing countries for the period 1970-1987. However, their findings show striking contrasts. Whereas the former finds that the growth in public investment in T\&C Granger causes GDP for the 15 developing countries in their dataset, the latter finds that the causality runs from GDP growth to public investment in $\mathrm{T} \& \mathrm{C}$ sector for a panel of 32 developing countries. Neither finds causality in the opposite direction.

The causality between investment in $\mathrm{T} \& \mathrm{C}$ and economic development is also examined via time series data. Groote et al. (1999) conducts Granger causality test in a multi-equation vector auto-regressive (VAR) model for the Netherlands in the 1853-1913 period, finding that infrastructure investment in T\&C positively causes GDP, but that GDP negatively affects investment in T\&C. Another study examining the same relationship in South Africa for 18752001 by Fedderke et al. (2005) similarly finds bidirectional causality between different definitions of economic infrastructure, one of which is $\mathrm{T} \& \mathrm{C}$, and economic growth via a cointegration analysis rather than a Granger causality framework. Cullison (1993) examines the effects of government investment in both physical and human capital on economic growth. He uses Granger causality tests to determine the correlation between 21 different types of government spending and economic growth in the U.S. using a VAR model. Making use of data for 1955-1992, he finds no causality from transportation spending including railways, air, and highways to economic growth.

Yet there are other studies pointing to unidirectional causality between further disaggregated variables of transportation and different measures of economic growth. Zhang and Fan (2004) conducts a Granger causality test in a general method of moments (GMM) framework to study the relationship between road density and agricultural productivity growth of 290 districts of rural India in 1971-1994. They find a unidirectional causality from the former to the latter. Likewise, Jiwattanakulpaisarn et al. (2009) employs the same methodology for the 48 states in the U.S. and arrives at a similar conclusion of unidirectional causality running from highway infrastructure investment to private sector employment. In contrast, Fernandes and Pacheco (2010) determine unidirectional Granger causality from GDP to demand for domestic air transport in Brazil between 1966 and 2006.

The hitherto evidence indeed puts forth mixed results for the causality between transportation and economic growth. In this study, we employ a larger data set 
and more refined technical analysis to verify the direction of the Grangercausality between transportation and GDP. We aim to supply more substantial evidence on the endogenity of transportation and GDP by employing a panel data set Granger-causality test for EU-15 countries between 1970 and 2008. The reason for choosing EU countries for this specific time period is their status as high income economies with well-structured transportation sectors, thus providing a stable basis on which to analyze and identify the main factors in the issue at hand. We find that bi-directional Granger-causality is the leading type of causality for our sample of 15 countries. Instances of one-way or no Granger-causality were mainly found to correspond with countries with the lowest per capita ranks in 1970 and/or 2008, including Portugal, Greece and Italy. We argue that bi-directional Granger causality between income and transportation is observed only after an economy has completed its transition in terms of economic development. Therefore, we speculate that not all EU-15 economies have yet completed their transition to a steady state.

The organization of the paper is as follows. Section 2 summarizes the methodology of Granger non-causality test for heterogeneous panel data models, adapted from Erdil and Yetkiner (2009), and presents the results. We show that bi-directional Granger-causality is the leading type of causality for our sample of 15 countries. Section 3 is reserved for conclusion.

\section{A Panel Data Approach \\ 2.1 The Methodology ${ }^{2}$}

There are alternative approaches to running Granger (1969) causality tests in panel data models. In this study, we employ the approach proposed by Hurlin and Venet (2001), Hurlin (2004a), Hurlin (2004b), and Hansen and Rand (2006), which treat the autoregressive coefficients and regression coefficient slopes as constants. As the methodology is discussed in detail by Erdil and Yetkiner (2009), we will present here a parsimonious summary. Let us consider two covariance stationary variables, $\mathrm{x}$ and $\mathrm{y}$, observed on $\mathrm{T}$ periods and on N cross-section units. Granger (1969) causality is defined as follows: the variable $x_{i, t}$ is causing $y_{i, t}$ if we are better able to predict $y_{i, t}$ by using all available information, compared to the use of information without $x_{i, t}$, for each individual $i \epsilon[1, N]$. For matter of tractability, we will consider only linear ones and for this reason, we will study a time-stationary VAR representation, used for a panel data set. For each cross-section unit $i$ and time period $t$, we estimate the following model:

\footnotetext{
${ }^{2}$ This sub-section heavily draws from Erdil and Yetkiner (2009).
} 
$y_{i, t}=\sum_{k=1}^{p} \beta_{k} y_{i, t-k}+\sum_{k=0}^{p} \theta_{k} x_{i, t-k}+u_{i, t}$

where $\mathrm{u}$ is normally distributed with $u_{i, t}=\alpha_{i}+\varepsilon_{i, t}, \mathrm{p}$ is the number of lags, and $\varepsilon_{i, t}$ are i.i.d. $\left(0, \sigma^{2}\right)$. It is assumed that the autoregressive coefficients $\beta_{k}$ and the regression coefficients $\theta_{k}$ 's are constant for $k \in[1, N]$. Moreover, it is further assumed that the parameters $\beta_{k}$ are identical for all individual countries, while the coefficients $\theta_{k}$ could have country-specific dimensions. In other words, the model utilized in this study is a panel data model with fixed coefficients (i.e., fixed effects model). Finally, the residuals are assumed to satisfy the standard properties, i.e., they are independently, identically, and normally distributed, and free from heteroscedasticity and autocorrelation.

In testing causality with panel data, the researcher should pay attention to the question of heterogeneity between cross-section units. The first source of heterogeneity is caused by permanent cross sectional disparities. A pooled estimation without the heterogeneous intercepts could lead to a bias of the slope estimates and could result in a fallacious inference in causality tests (Hurlin, 2004a). Another basis of heterogeneity caused by heterogeneous regression coefficients $\theta_{k}$ is more problematic than the first one. In sum, the analysis of causality for panel data sets should consider the different sources of heterogeneity of the data-generating process. Therefore, there are different types of causality hypothesis to be tested in a panel data set framework. These are summarized in Table 1.

The first test procedure, named as the homogenous and instantaneous noncausality hypothesis (HINC), is directed towards testing whether or not the $\theta_{k}$ 's of $x_{i, t-k}$ are simultaneously null for all individual $i$ and all lag $k$. For testing $N p$ linear restrictions in (HINC), the respective Wald statistics (the first box in the third column) is used. Since the individual effects, $\alpha_{i}$, are assumed to be fixed, $S S R_{u}$ and $S S R_{r}$ are SSR obtained from the maximum likelihood (ML) estimation, which, in this case, corresponds to the fixed effects (FE) estimator.

If the HINC hypothesis is rejected, there are two possibilities. The first one is the homogenous causality hypothesis (HC) and takes place if all the coefficients $\theta_{k}$ are identical for all lag $k$ and are statistically different from zero. In other words, the aim is to test whether $\theta_{k}$ 's in (1) are equal. As in the case of HINC, since country fixed effects, $\alpha_{i}$, are assumed to be fixed, the ML estimator is consistent with the FE estimator. 
Granger-Causality between Transportation and Output

Table 1: Types of Causality tested in a Panel Data Framework ${ }^{3}$

\begin{tabular}{|l|l|l|}
\hline Name & Hypothesis Tested & Test statistic \\
\hline $\begin{array}{l}\text { Homogenous } \\
\text { and }\end{array}$ & $H_{0}: \theta_{k}=0 \forall i \in[1, N], \forall k \in[0, p]$ & $F_{H I N C}=\frac{\left(S S R_{r}-S S R_{u}\right) /(N p)}{S_{u} /[N T-N(1+p)-p]}$ \\
$\begin{array}{l}\text { Instantaneous } \\
\text { Non-Causality } \\
\text { hypothesis } \\
\text { (HINC) }\end{array}$ & $H_{1}: \theta_{k} \neq 0 \quad \exists(i, k)$ & \\
\hline $\begin{array}{l}\text { Homogenous } \\
\text { Causality } \\
\text { hypothesis } \\
\text { (HC) }\end{array}$ & $H_{0}: \theta_{k}^{i}=\theta_{k}^{j} \forall i, j \in[1, N], \forall k \in[0, p]$ & $F_{H C}=\frac{\left(S S R_{r}^{\prime}-S S R_{u}\right) /[p(N-1)]}{S_{u} /[N T-N(1+p)-p]}$ \\
\hline $\begin{array}{l}\text { Heterogeneou } \\
\text { s Non- } \\
\begin{array}{l}\text { Causality } \\
\text { hypothesis } \\
\text { (HENC) }\end{array}\end{array}$ & $H_{0}: \theta_{k}^{i} \neq \theta_{k}^{j} \quad \exists(i, j, k)$ & \\
\hline
\end{tabular}

Note: $\mathrm{SSR}_{\mathrm{u}}$ stands for the sum of squared residuals unrestricted and $\mathrm{SSR}_{\mathrm{r}}$ stands for the sum of squared residuals restricted for the respective $\mathrm{H}_{0}$.

If the $\mathrm{HC}$ hypothesis is also rejected, this means that the process is nonhomogenous and no homogenous causality relationships can be obtained (Hurlin, 2004a). Nonetheless, such a situation need not entail the lack of any causality relationships between two variables. It may still be possible that for one or more cross-section units, there exist causality relationships. Hence, the variable $x$ causes the variable $y$ for a single country or for a subgroup of crosssection units. In this study however, we do not examine subgroups. The last step is to test the heterogeneous non-causality hypothesis (HENC). In this case, the nullity of all the coefficients of the lagged explanatory variable $x_{i, t-k}$ is tested for each cross-section unit. These $N$ individual tests identify the crosssection unit for which there are no causality relationships. If the HENC hypothesis is failed to reject, this means that there exists a single country for which the variable $x$ does not cause the variable $y$.

\subsection{The Data and the Model}

We use data derived from OECD Stat Extracts Database for 15 EU member countries in an attempt to test the bidirectional causality between real per capita GDP and transportation in a panel data setting. ${ }^{4}$ Real GDP per capita ${ }^{5}$ and inland freight transportation per capita in tons are taken as the output and

\footnotetext{
${ }^{3}$ Please refer to Erdil and Yetkiner (2009) for details.

${ }^{4}$ http://stats.oecd.org/Index.aspx

${ }^{5}$ US \$, constant prices, constant PPP, OECD base year 2005.
} 
transportation variables, respectively. Therefore, we have a balanced panel data set for real GDP per capita (GDP) and transportation (TRP) on 15 countries between 1970 and 2008. The following two models are estimated:

$$
\begin{aligned}
& \Delta G D P_{i, t}=\sum_{k=1}^{p} \beta_{k} \Delta G D P_{i, t-k}+\sum_{k=0}^{p} \theta_{k} \Delta T R P_{i, t-k}+u_{i, t} \\
& \Delta T R P_{i, t}=\sum_{k=1}^{p} \beta_{k} \Delta T R P_{i, t-k}+\sum_{k=0}^{p} \theta_{k} \Delta G D P_{i, t-k}+v_{i, t}
\end{aligned}
$$

For both variables, we take the natural logarithms. We further difference the data in order to eliminate possible unit roots. ${ }^{6}$

\subsection{Bi-directional Causality between Transportation and Income: Pooled Estimation}

As a first step to exploring the bi-directional causality between transportation and income, the lag lengths were chosen for both variables. Table 2 presents Akaike Information Criterion (AIC) figures for each variable. Consequently, we choose two lags for both GDP and TRP.

Table 2. Number of Lags for GDP and TRP

\begin{tabular}{|c|c|c|c|c|}
\hline Variable & Lag1 & Lag2 & Lag3 & Number of Lags \\
\hline GDP & -1.223 & $\mathbf{- 1 . 3 9 3}$ & -1.376 & 2 \\
\hline TRP & -4.535 & $\mathbf{- 4 . 6 8 3}$ & -4.670 & 2 \\
\hline
\end{tabular}

After choosing the lag lengths, equations (2) and (3) were estimated for each country group in order to test HINC and HC hypothesis. Table 3 demonstrates the values of Wald statistics for testing two types of homogenous causality hypothesis, namely HINC and HC. ${ }^{7}$ The test results allow us to reject both of the null hypotheses at $1 \%$ level of significance, indicating there is no homogenous causality between GDP and TRP. Rejecting the null hypothesis of HINC shows the existence of a causality relation between GDP and TRP. The next question is whether the causality is an overall (homogenous) causality for

\footnotetext{
${ }^{6}$ Indeed, we found that the original series of GDP and TRP contain unit root. According to Hadri and Breitung panel unit root tests series are found integrated of order 1. Breitung tests the existence of unit root as null hypothesis. The test statistics of both series show that we cannot reject the null hypothesis. Hadri tests the stationarity of series as null hypothesis. Test statistics lead us to reject at $1 \%$ significance level.

${ }^{7}$ Please refer to of rows 1 and 2 in Table 1.
} 
Granger-Causality between Transportation and Output

each country group, or originates from causality relations for individual countries (heterogeneous). The results verify the existence of a heterogeneous causality as a result of testing HC hypothesis.

Table 3. Test Results for homogeneous causality hypotheses

\begin{tabular}{|c|c|c|c|}
\hline Country Group & Test & $\begin{array}{c}\text { Causality from } \\
\text { GDP to TRP }\end{array}$ & $\begin{array}{c}\text { Causality from } \\
\text { TRP to GDP }\end{array}$ \\
\hline \multirow{2}{*}{ EU-15 } & HINC & $162.436 * * *$ & $6.723 * * *$ \\
\cline { 2 - 4 } & HC & $126.747 * * *$ & $9.081 * * *$ \\
\hline
\end{tabular}

$* * *$ Reject $\mathrm{H}_{0}$ at $1 \%$ level of significance.

The next step for an attempt to search for causality is to discover the individual countries' contribution to the existence of causality. For this purpose, we estimate equations (2) and (3) where $\theta_{k}$ 's differ among countries in our data set and HENC hypotheses are tested for each individual country. The results of $F_{H E N C}$ test (given in the last row of Table 1 ) are presented at Table $4 .^{8}$

Table 4: Test Results for Heterogeneous Causality Hypotheses

\begin{tabular}{|c|c|c|c|}
\hline Country & Test & $\begin{array}{c}\text { Causality from } \\
\text { GDP to TRP }\end{array}$ & $\begin{array}{c}\text { Causality from } \\
\text { TRP to GDP }\end{array}$ \\
\hline Austria & HENC & $3.565^{* *}$ & $2.369^{*}$ \\
\hline Belgium & HENC & $7.996^{* * *}$ & $6.354^{* * *}$ \\
\hline Denmark & HENC & $4.875^{* * *}$ & 2.131 \\
\hline Finland & HENC & $6.627^{* * *}$ & $3.765^{* *}$ \\
\hline France & HENC & $4.127^{* *}$ & $3.256^{* *}$ \\
\hline Germany & HENC & $15.783^{* * *}$ & $7.593^{* * *}$ \\
\hline Greece & HENC & 1.625 & 1.766 \\
\hline Ireland & HENC & 1.177 & $2.974^{* *}$ \\
\hline Italy & HENC & $4.475^{* * *}$ & $5.607 *$ \\
\hline Luxembourg & HENC & $7.726^{* * *}$ & $9.524^{* * *}$ \\
\hline Netherlands & HENC & 0.853 & $12.139^{* * *}$ \\
\hline Portugal & HENC & $10.946^{* * *}$ & 1.494 \\
\hline Spain & HENC & $2.426^{*}$ & 0.958 \\
\hline Sweden & HENC & $5.925^{* * *}$ & $6.658^{* * *}$ \\
\hline United Kingdom & HENC & & \\
\hline$* * *$ Reject Ho $H_{0}$ at 1\% level of significance, $* *$ Reject $H_{0}$ at $5 \%$ level of significance, $*$ Reject $H_{0}$ at $10 \%$ level \\
\hline
\end{tabular}

${ }^{8}$ The detailed F-statistics and the estimation output for these tests can be requested from the authors. 
According to Table 4, bi-directional causality relation is observed for 8 countries out of 15 , meaning that for approximately $53 \%$ of the countries in our data set, bidirectional causality both from GDP to TRP and TRP to GDP are relevant. The results, however, become more interesting if we order countries in accordance with their GDP per capita. We first list them with respect to their income per capita in 1970:

Table 5. Test Results for Heterogeneous Causality Hypotheses

(Ranked by 1970 GDP per capita)

\begin{tabular}{|c|c|c|c|c|}
\hline $\begin{array}{c}\text { Rank } \\
\text { in } 1970\end{array}$ & Country & $\begin{array}{c}\text { Real GDP } \\
\text { per capita (1970) }\end{array}$ & $\begin{array}{c}\text { Causality from } \\
\text { GDP to TRP }\end{array}$ & $\begin{array}{c}\text { Causality from } \\
\text { TRP to GDP }\end{array}$ \\
\hline 1 & Luxembourg & 5505 & $4.475^{* * *}$ & $5.973^{* * *}$ \\
\hline 2 & Sweden & 4586 & $2.426^{*}$ & 0.958 \\
\hline 3 & Denmark & 4218 & $4.875^{* * *}$ & 2.131 \\
\hline 4 & Netherlands & 4015 & $7.726^{* * *}$ & $9.524^{* * *}$ \\
\hline 5 & Belgium & 3832 & $7.996^{* * *}$ & $6.354^{* * *}$ \\
\hline 6 & Austria & 3809 & $3.565^{* * *}$ & $2.369^{*}$ \\
\hline 7 & Germany & 3775 & $15.783^{* * *}$ & $7.593 * * *$ \\
\hline 8 & France & 3577 & $4.127^{* *}$ & $3.256^{* *}$ \\
\hline 9 & United Kingdom & 3568 & $5.925^{* * *}$ & $6.658^{* * *}$ \\
\hline 10 & Italy & 3387 & 1.612 & $2.607 *$ \\
\hline 11 & Finland & 3335 & $6.627^{* * *}$ & $3.765^{* *}$ \\
\hline 12 & Greece & 2913 & 1.625 & 1.766 \\
\hline 13 & Spain & 2686 & $10.946^{* * *}$ & 1.494 \\
\hline 14 & Ireland & 2292 & 1.177 & $2.974^{* *}$ \\
\hline 15 & Portugal & 1864 & 0.853 & $12.139^{* * *}$ \\
\hline
\end{tabular}

$* * *$ Reject $H_{0}$ at $1 \%$ level of significance, $* *$ Reject $H_{0}$ at $5 \%$ level of significance, *Reject $H_{0}$ at $10 \%$ level of significance.

Countries ranked with respect to their 1970 GDP per capita levels reveal a clear pattern: those ranked as high income countries in 1970 can be seen to have either bi-directional causality or causality running from GDP to TRP (the first nine countries). On the other hand, those listed at the end of the rank evidently either have no causality in Granger sense (e.g., Greece) or mixed results (some have causality running from TRP to GDP and some other way around; it is only Finland that has bi-directional causality). Heuristically speaking, we conjecture that bi-directional Granger causality between income and transportation is observed after a certain level of development is achieved. 
Granger-Causality between Transportation and Output

In contrast, mixed results are observed in those countries in which transition is incomplete. We also ranked the list of countries according to their 2008 income in Table 6:

Table 6. Test Results for Heterogeneous Causality Hypotheses

(Ranked by 2008 GDP per capita)

\begin{tabular}{|c|c|c|c|c|c|}
\hline $\begin{array}{c}\text { Rank } \\
\text { in 1970 }\end{array}$ & $\begin{array}{c}\text { Rank } \\
\text { In 2008 }\end{array}$ & Country & $\begin{array}{c}\text { Real GDP } \\
\text { per capita (2008) }\end{array}$ & $\begin{array}{c}\text { Causality from } \\
\text { GDP to TRP }\end{array}$ & $\begin{array}{c}\text { Causality from } \\
\text { TRP to GDP }\end{array}$ \\
\hline 1 & 1 & Luxembourg & 84713 & $4.475^{* * *}$ & $5.973^{* * *}$ \\
\hline 14 & 2 & Ireland & 41493 & 1.177 & $2.974 * *$ \\
\hline 4 & 3 & Netherlands & 41063 & $7.726^{* * *}$ & $9.524^{* * *}$ \\
\hline 6 & 4 & Austria & 37858 & $3.565^{* *}$ & $2.369^{*}$ \\
\hline 3 & 5 & Denmark & 36808 & $4.875^{* * *}$ & 2.131 \\
\hline 2 & 6 & Sweden & 36790 & $2.426^{*}$ & 0.958 \\
\hline 11 & 7 & Finland & 35918 & $6.627^{* * *}$ & $3.765^{* *}$ \\
\hline 9 & 8 & United Kingdom & 35631 & $5.925^{* * *}$ & $6.658^{* * *}$ \\
\hline 7 & 9 & Germany & 35432 & $15.783^{* * *}$ & $7.593^{* * *}$ \\
\hline 5 & 10 & Belgium & 35288 & $7.996^{* * *}$ & $6.354^{* * *}$ \\
\hline 8 & 11 & France & 33090 & $4.127^{* *}$ & $3.256^{* *}$ \\
\hline 13 & 12 & Spain & 31455 & $10.946^{* * *}$ & 1.494 \\
\hline 10 & 13 & Italy & 31253 & 1.612 & $2.607^{*}$ \\
\hline 12 & 14 & Greece & 28896 & 1.625 & 1.766 \\
\hline 15 & 15 & Portugal & 23283 & 0.853 & $12.139^{* * *}$ \\
\hline
\end{tabular}

$* * *$ Reject $H_{0}$ at $1 \%$ level of significance, **Reject $H_{0}$ at $5 \%$ level of significance, *Reject $H_{0}$ at $10 \%$ level of significance.

Our interpretation does not change in the sense that while developed economies have a strong tendency to show bi-directional Granger causality between income and transportation or causality from GDP to transportation (reverse causality), those that are listed at the bottom have an equally strong tendency to show no Granger causality or Granger causality running from transportation to GDP.

\section{Concluding Remarks}

We applied the Granger causality approach to a panel data model with fixed coefficients in order to determine the relation between GDP and transportation, which is measured in terms of freight. We found significant evidence of bidirectional causality. The results of testing HINC hypothesis clearly reveal 
the existence of bi-directional causality for our sample. However, this causality is not homogenous, which is evident from the tests of HC hypotheses. The tests for heterogeneous causality demonstrate that the leading type of causality is bidirectional. We also observe that both for 1970 and 2008, only well developed economies clearly show bi-directional causality. In contrast, no such clear tendency can be seen in other countries, which exhibit mixed results, indicating a strong linkage between the level of development and transportation. We argue for the possibility that some EU-15 countries have yet to complete the transition to a steady state, a position which is supported by the Grangercausality analysis. 
Granger-Causality between Transportation and Output

\section{References}

Aschauer, D.A., (1989). "Is Public Expenditure Productive?", Journal of Monetary Economics, 23 (2), 177-200.

Berndt, E. R., and Hansson, B., (1992). "Measuring the Contribution of Public Infrastructure Capital in Sweden", Scandinavian Journal of Economics 94, (supplement 1992), 151-168.

Boarnet, M.G., (1996). "The Direct and Indirect Economic Effects of Transportation Infrastructure", University of California Transportation Center, Berkeley, Working Paper No. 340.

Boarnet, M.G., (1998). "Spillovers and locational effects of public infrastructure", Journal of Regional Science, 38 (3), 381-400.

Boopen, S., (2006). "Transport Infrastructure and Economic Growth: Evidence from Africa Using Dynamic Panel Estimates", The Empirical Economics Letters, 5 (1), 37-52.

Bose, N. and Haque, M.E. (2005). "Causality between Public Investment in Transport and Communication and Economic Growth", Journal of Economic Development, 30 (1), 95-106.

Bougheas, S., Demetriades, P.O., Mamuneas, T.P., (2000). "Infrastructure, Specialization, and Economic Growth", The Canadian Journal of Economics / Revue canadienne d'Economique, 33 (2), 506-522.

Chamberlain, G. (1982), "Multivariate Regression Models for Panel Data", Journal of Econometrics, 18 (1), 5-46.

Conrad, K., and Seitz, H., (1994). "The Economic Benefits of Public Infrastructure", Applied Economics, 26 (4), 303-311.

Crihfield, J. B., and Panggabean, M. P. H., (1995). "Is Public Infrastructure Productive? A Metropolitan Perspective using New Capital Stock Estimates", Regional Science and Urban Economics, 25 (5), 607-630.

Cullison, W. E., (1993). "Public Investment and Economic Growth", Federal Reserve Bank of Richmond Economic Quarterly, 79 (4), 19-34.

Duffy-Deno, K. T. and Eberts, R.W., (1991). "Public Infrastructure and Regional Economic Development: A Simultaneous Equations Approach". Journal of Urban Economics, 30 (3), 329-343.

Eisner, R. (1991). "Infrastructure and Regional Economic Performance". New England Economic Review, Federal Reserve Bank of Boston, Sept./Oct. 1991, 47-58.

Erdil, E. and I.H. Yetkiner, (2009). "The Granger-Causality between Health Care Expenditure and Output: A Panel Data Approach", Applied Economics, 41 (4), 511-518. 
Fedderke, J. W., Perkins, P., and Luiz, J.M. (2006). "Infrastructural Investment in Long-run Economic Growth: South Africa 1875-2001", World Development, 34 (6), 1037-1059.

Fernald, J. G., (1999). "Roads to Prosperity? Assessing the Link between Public Capital and Productivity", The American Economic Review, 89 (3), 619-638.

Fernandes, E. and Pacheco, R. R., (2010). "The Causal Relationship between GDP and Domestic Air Passenger Traffic in Brazil", Transportation Planning and Technology, 33 (7), 569-581.

Florens, J.-P. and Mouchart, M., (1982). "Note on Non-causality", Econometrica, 50 (3), 583-591.

Garcia-Mila, T. and McGuire, T.J., (1992). "The Contribution of Publicly Provided Inputs to States' Economies", Regional Sciences and Urban Economics, 22 (2), 229-241.

Garcia-Mila, T., McGuire, T., and Porter, R.H., (1996). "The effect of public capital in state-level production functions reconsidered", The Review of Economics and Statistics, 78 (1), 177-180.

Granger, C.W.J., (1969). "Investigating Causal Relations by Econometric Models and Cross-Spectral Methods", Econometrica, 37 (3), 424-438.

Groote, P., Jacobs, J. and Sturm, J.E, (1999). "Output Effects of Transport Infrastructure: The Netherlands, 1853-1913”, Tijdschrift voor Economische en Sociale Geografie, 90 (1), 97-109.

Hansen H. and Rand J., (2006). "On the Causal Links between FDI and Growth in Developing Countries", World Economy, 29(1), 21-41.

Haque, M.E. and Kim, D.H. (2003), "Public Investment in Transportation and Communication and Growth: A Dynamic Panel Approach", The University of Manchester, Centre for Growth and Business Cycle Research Discussion Paper Series, 31.

Hurlin, C., (2004a). "Testing Granger Causality in Heterogeneous Panel Data Models with Fixed Coefficients", Miméo, University of Orléans.

Hurlin, C., (2004b). "A Note on Causality Tests in Panel Data Models with Random Coefficients", Miméo, University of Orléans.

Hurlin, C. and Venet, B., (2001). "Granger Causality Tests in Panel Data Models with Fixed Coefficients", Miméo, University Paris IX.

Jiwattanakulpaisarn, P., Noland, R. B., Graham, D. J., and Polak, J. W., (2009). "Highway Infrastructure and State-Level Employment: A Causal Spatial Analysis", Papers in Regional Science, 88 (1), 133-159.

Jones, B. D., (1990). "Public Policies and Economic Growth in the American States”, Journal of Politics, 52 (1), 219-233. 
Kim, E., (2002). "Determinants of Optimal Level of Transportation Infrastructure", Journal of Urban Planning and Development, 128(3), 150163.

Lakshmanan, T.R., (2007). "The Wider Economic Benefits of Transportation: An Overview", OECD International Transport Forum, Joint Transportation Research Centre Discussion Paper, No: 2007-8.

Lynde, C. and Richmond, J., (1993). "Public Capital and Long-Run Cost in U.K. Manufacturing”, The Economic Journal, 103 (419), 880-893.

Mofidi, A. and Stone, J.A., (1990). "Do state and local taxes affect economic growth?", The Review of Economics and Statistics, 72 (4), 686-691.

Moonmaw, R. L., Mullen, J. K. and Martin, W., (1995). "The interregional impact of infrastructure capital", Southern Economic Journal, 61(3), 830845.

Munnell, A.H., (1990). "Why Has Productivity Declined? Productivity and Public Investment", New England Economic Review, Jan. / Feb.1990, 3-22.

Munnell, A.H. and Cook, L.M., (1990). "How does Public Infrastructure Affect Regional Economic Performance", New England Economic Review, September, 11-33.

Nadiri, M.I. and Mamuneas, T.P., (1994). "The Effect of Public Infrastructure and R\&D Capital on the Cost Structure and Performance of U.S. Manufacturing Industries", The Review of Economics and Statistics, 76 (1), 22-37.

Randolph, S., Bogetic, Z., and Hefley, D., (1996). "Determinants of Public Expenditure on Infrastructure: Transportation and Communication", World Bank Policy Research Working Paper, No. 1661.

Reynolds, P.D. and Maki, W., (1990). "U.S. regional characteristics, new firms, and economic growth" Working paper, University of Warwick, UK.

Seitz, H., (1993). "A dual economic analysis of the benefits of the public road network", Annals of Regional Science, 27(3), 223-239.

Singletary, L., Henry, M., Brooks, K. and London, J., (1995). "The impact of highway investment on new manufacturing employment in South Carolina: A small region spatial analysis", The Review of Regional Studies 25 (summer), 37-55.

Zhang, X., and Fan, S., (2004). "How Productive is Infrastructure? A New Approach and Evidence from Rural India", The American Journal of Agricultural Economics, 86 (2), 492-501.

Zhou, J., Yang, L., Xu, Y., Liu, C., (2007). "The economic performance of transportation infrastructure: an empirical study on the recent development of China", World Transactions on Engineering and Technology Education UICEE, 6(1), 193-197. 